\title{
All Sites
}

National Cancer Institute

\section{Source}

National Cancer Institute. All Sites. NCI Thesaurus. Code C13399.

Anything relevant to all anatomic sites - non-specific. 